\title{
ANALISIS PERBANDINGAN PERDAGANGAN INTERNASIONAL INDONESIA - QATAR SEBELUM DAN SESUDAH DISEPAKATINYA PERSETUJUAN PENGHINDARAN PAJAK BERGANDA ANTARA INDONESIA-QATAR
}

\author{
Andriansyah \\ Nurma Risa \\ Fakultas Ekonomi Jurusan Akuntansi Universitas Islam 45 Bekasi \\ Jl. Cut Meutia Bekasi \\ Email: nurma.risa@gmail.com
}

Abstract

The purpose of this study is analizing value of international commerce before and after Indonesia - Qatar tax treaty committed. This research is quantitative rasearch and use real export and import value between Indonesia - Qatar for the periode 2004-2007 (before treaty) and 2008-2013 (after treaty). Data analysis is using independent sample t-test. The result of this study are tax treaty between Indonesia and Qatar don't have any impact to export value, but in the other hand, this treaty has impact significantly to import value of Indonesia. This research gives a global picture, that a tax treaty can influence the international commerce value between two countries which have committed. Suggestion for next research is not only the value of export and import as one variable but also multivariable.

Keywords: internasional tax law, tax treaty, internasional trade

Abstrak

Tujuan penelitian untuk menguji dan menganalisis nilai perdagangan internasional sebelum dan sesudah disepakatinya P3B antara Indonesia-Qatar. Metode 
penelitian menggunakan metode kuantitatif. Data penelitian yang digunakan adalah data realisasi perdagangan ekspor dan impor antara Indonesia-Qatar periode sebelum P3B (2004-2007) dan periode sesudah P3B (2008-2011). Hasil penelitian diperoleh bahwa disepakatinya P3B Indonesia-Qatar tidak mempengaruhi nilai perdagangan ekspor secara umum tetapi mempengaruhi secara khusus, Dan disepakatinya P3B Indonesia-Qatar mempengaruhi nilai perdagangan impor. Dapat disimpulkan bahwa disepakatinya P3B/Tax Treaty dapat mempengaruhi nilai perdagangan internasional antara kedua negara persetujuan ditinjau dari segi aspek yang menjadi objek kesepakatan kedua negara tersebut. Diharapkan untuk penelitian selanjutnya lebih mengembangkan sampel area penelitian sehingga dapat diketahui dampak dari P3B dibelahan negara dunia lainnya.

Kata kunci: internasional tax law, tax treaty, internasional trade

\section{PENDAHULUAN}

Semakin berkembangnya transaksi perdagangan internasional dapat membawa dampak positif dan negatif pada suatu negara. Dampak positifnya dapat meningkatkan penerimaan suatu negara, yang antara lain bersumber dari sektor pajak. Transaksi perdagangan internasional akan mengakibatkan meningkatnya penerimaan pajak sehingga akan memberikan kontribusi yang besar untuk menggerakan perekonomian di dalam negeri. Dampak negatifnya dapat terjadinya permasalahan diantara negara-negara yang melakukan transaksi perdagangan internasional karena adanya perbedaan tarif pajak maupun perbedaan pemberian fasilitas perpajakan.

Transaksi perdagangan antara kedua negara atau beberapa negara dapat menimbulkan permasalahan tersendiri dari sisi perpajakan, yaitu bentrokan yuridiksi peraturan perpajakan antarnegara. Hal ini perlu diatur dan disepakati oleh kedua negara yang bersangkutan ataupun diseluruh dunia guna meningkatkan perekonomian dan perdagangan antarnegara agar tidak menghambat investasi penanaman modal asing akibat pengenaan pajak berganda yang akan memberatkan wajib pajak yang berkedudukan dikedua negara yang mengadakan transaksi perdagangan internasional. Masing-masing negara dapat saja mengenakan pajak atas penghasilan yang berasal dari transaksi perdagangan internasional tersebut.

Menurut Pranata (2012) menyatakan bahwa: "Bebeberapa tahun ini Qatar salah satu mitra dagang Indonesia telah menjadi negara yang memiliki peran yang penting dalam percaturan perdagangan internasional. Disebabkan Qatar yang kaya akan gas bumi ini menjadi negara terkaya di dunia tahun 2012". Wajar saja karena data Forbes menunjukkan Produk Domestik Bruto (PDB) perkapitanya mencapai US\$ 88.000 (Rp 836 juta) pada tahun 2012, bergantung pada sumber gas alaminya yang merupakan terbesar ketiga di dunia untuk segi pemasukan. Qatar berinvestasi besar-besaran di infrastruktur untuk melancarkan dan mengekspor komoditas 
tersebut. Qatar merupakan salah satu negara havent tax country dimana negara ini tidak mengenakan pajak penghasilan pribadi, dividen, royalti, laba, capital gain dan properti. Namun warga negara Qatar harus membayar 5\% dari penghasilan mereka untuk biaya keamanan sosial, sementara perusahaan berkontribusi $10 \%$ dari neto untuk pendanaan tersebut, serta pengenaan pajak tidak langsung lainnya meliputi pengenaan biaya $5 \%$ untuk barang-barang impor.

Terdapat dua otoritas yang memiliki kepentingan dalam pengenaan pajak yang terkait dengan hak pemajakan pendapatan atas kepemilikan/beneficial owner, yaitu negara asal wajib pajak (asas domisili) dan negara tempat wajib pajak mendapatkan penghasilan (asas sumber). Permasalahan perpajakan muncul ketika kedua negara tersebut hendak mengenakan pajak atas jenis pendapatan yang sama (passive income). Jika pengenaan pajak didasarkan atas domisili, maka aspek keadilan dan efisiensi investasi akan dapat lebih dipastikan. Tetapi di sisi lain sangatlah sulit menentukan dengan pasti penghasilan dari wajib pajak yang berasal dari luar negeri. Sebaliknya, jika pengenaan pajak didasarkan atas asas sumber, maka akan mudah menentukan dengan pasti nilai penghasilan yang akan dikenai pajak. Tetapi di sisi lain, hal itu kurang memenuhi keadilan dan efisiensi investasi juga tidak dapat dipastikan. Di samping itu tarif pajak yang dikenakan untuk objek pajak yang sama juga berbeda antara pengenaan pajak yang didasarkan atas asas sumber dengan yang didasarkan atas asas domisili. Hal lain yang perlu diperhatikan yaitu bahwa hak suatu negara untuk mengenakan pajak atas penghasilan berdasarkan residence jurisdiction-nya, tetapi di sisi lain juga merupakan hak negara lain untuk memungut pajak penghasilan berdasarkan source jurisdiction. Hal ini menimbulkan pajak berganda internasional (international double taxation) karena wajib pajak dikenakan pajak berganda atas pendapatan (income) yang sama oleh negara yang berbeda dalam periode yang sama juga.

Solusi untuk mengatasi masalah pajak berganda internasional (international double taxation), yaitu dengan adanya kebijakan perpajakan internasional untuk mengatur hak pengenaan pajak yang berlaku disuatu negara, dimana setiap negara dipastikan mengatur adanya pajak di wilayah kedaulatan negara tersebut. Kebijakan ini disebut dengan Persetujuann Penghindaran Pajak Berganda (P3B)/Tax Treaty. Persetujuan Penghindaran Pajak Berganda (P3B)/tax treaty disinyalir mempunyai pengaruh dalam meningkatkan arus perdagangan. Beberapa literatur mendukung pendapat ini, namun beberapa literatur juga menyatakan bahwa tidak ada pengaruh yang signifikan antara P3B dengan arus perdagangan. Penelitian ini dilakukan untuk memberikan analisis terhadap nilai perdagangan ekspor dan impor sebelum dan sesudah disepakatinya P3B antara Indonesia-Qatar. P3B adalah perjanjian/persetujuan/kesepakatan yang dilakukan oleh dua/lebih negara/yuridiksi pajak yang mengatur perlakuan pajak penghasilan atas penghasilan yang diterima oleh wajib pajak dalam negeri dari dua/lebih negara/yurisdiksi pajak yang berbeda. 
Sejak 30 April 2006 pemerintah Indonesia dan Qatar berupaya agar dapat melaksanakan persetujuan penghindaran pajak berganda guna melindungi warganya yang akan melakukan transaksi perdagangan diantara kedua negara dan pada 1 Januari 2008 Indonesia dan Qatar resmi menyepakati persetujuan penghidaran pajak berganda dengan ratifikasi P3B dengan nama kesepakatan "Agreement Between The Government Of The Republic Of Indonesia And The Government Of The State Of Qatar, For The Avoidance Of Double Taxation And The Prevention Of Fiscal Evasion With Respect To Taxes On Income.” Berdasarkan uraian latar belakang penelitian di atas maka dirumuskan masalah dalam penelitian ini adalah apakah terdapat perbedaan nilai perdagangan ekspor dan impor IndonesiaQatar sebelum dan sesudah disepakatinya Persetujuan Penghindaran Pajak Berganda antara Indonesia-Qatar.

\section{TINJAUAN PUSTAKA DAN PENGEMBANGAN HIPOTESIS}

\section{Teori Perdagangan Internasional}

Perdagangan internasional merupakan perdagangan antara dua negara atau lebih yang didasarkan kesepakatan bersama dimana kedua negara saling menjalin kerjasama terutama dibidang perekonomian. Tambunan (2011) dalam Yuniati (2013: 14) mendefinisikan bahwa perdagangan internasional merupakan perdagangan antar atau lintas negara yang mencakup ekspor dan impor. Perdagangan internasional dibagi menjadi dua kategori, yakni perdagangan barang (fisik) dan perdagangan jasa. Perdagangan jasa meliputi pembayaran bunga dan remittance seperti gaji Tenaga Kerja Indonesia (TKI) di luar negeri dan pemakaian jasa konsultan asing di Indonesia serta royalti atas teknologi (lisensi).

Pada prinsipnya ada dua faktor utama yang menyebabkan timbulnya perdagangan internasional, yakni faktor-faktor yang mempengaruhi permintaan dan penawaran. Ahli-ahli ekonomi menganggap perdagangan internasional sebagai mesin pertumbuhan ekonomi (Engine of Growth) dan pandangan tersebut berlaku hingga kini. Adapun beberapa pendapat ahli ekonomi dunia mengenai perdagangan internasional yang dikutip dari Yuniati (2013:14), sebagai berikut: (1) Adam Smith mengemukakan tentang diperolehnya keuntungan (Gain from Trade) dari perdagangan internasional, yaitu berupa kenaikan produksi dan konsumsi barang dan jasa. Dengan adanya perdagangan luar negeri suatu negara dapat menaikkan produksi barang dan jasa yang tidak dapat dijual di dalam negeri tetapi masih laku di luar negeri, sehingga akan terjadi ekspor-impor suatu negara dan terjadilah perluasan pasar. Perluasan pasar ini sebagai akibat keuntungan dari perdagangan luar negeri (internasional) disebut sebagai teori "doctrin vent for surplus". (2) John Stuart Mill mengemukakan bahwa perdagangan internasional dan hubungan dengan negara lain dapat mempertinggi tingkat produktivitas kegiatan produksi. Seperti halnya Smith, faktor yang menyebabkan perdagangan luar negeri menciptakan produksi 
adalah karena perluasan pasar. Uraian Mill inilah yang disebut sebagai teori "doctrin productivity".

\section{Pemajakan atas Ekspor-Impor}

Menurut Undang-Undang Pajak Pertambahan Nilai Barang dan Jasa dan Pajak Pertambahan Nilai atas Barang Mewah Nomor 42 tahun 2009 pasal 1 ayat (1) menjelaskan tentang daerah pabean adalah wilayah Republik Indonesia yang meliputi wilayah darat, perairan, dan ruang udara di atasnya, serta tempat-tempat tertentu di Zona Ekonomi Ekslusif dan landas kontinen yang di dalamnya berlaku UndangUndang yang mengatur mengenai kepabeanan.

\section{Ekspor}

Menurut Undang-Undang Pajak Pertambahan Nilai Barang dan Jasa dan Pajak Pertambahan Nilai atas Barang Mewah Nomor 42 tahun 2009 pasal 1 ayat (11) menjelaskan bahwa ekspor adalah mengeluarkan barang dari dalam ke luar wilayah pabean Indonesia dengan memenuhi ketentuan yang berlaku. Ketentuan umum di bidang ekspor biasanya meliputi hal-hal yang berhubungan dengan proses pengiriman barang ke luar negeri.

\section{Impor}

Menurut Undang-Undang Kepabeanan Nomor 10 Tahun 1995 dijelaskan tentang Ketentuan Umum menyatakan bahwa impor adalah kegiatan perdagangan dengan cara memasukkan barang dari luar negeri ke dalam wilayah pabean Indonesia dengan memenuhi ketentuan yang berlaku. Ketentuan umum di bidang impor biasanya meliputi hal-hal yang berhubungan dengan proses pengiriman barang ke dalam negeri. Barang impor dipungut Bea Masuk berdasarkan tarif setinggitingginya empat puluh persen dari nilai pabean untuk perhitungan Bea Masuk.

Pemungutan pajak atas impor tersebut, dilakukan oleh Ditjen Bea dan Cukai (DJBC). Dasar atas pengenaan pajak atas impor adalah nilai impor tersebut yaitu merupakan nilai berupa uang yang menjadi dasar pengenaan Bea Masuk ditambah Bea Masuk dan pungutan lainnya berdasarkan ketentuan pabean yang berlaku.

\section{Hukum Pajak Internasional}

Negara Indonesia mengadakan Tax Treaty bukanlah semata-mata keinginan dari negara kita, namun juga karena ada azas timbal-balik dan keinginan yang sama dari negara yang mengadakan persetujuan tersebut. Pengertian hukum pajak menurut beberapa pendapat ahli yang dikutip dalam Suandi (2008:251-252): (1) Menurut Buhler menyatakan bahwa hukum pajak internasional terbagi atas pengertian sempit dan luas: a) Hukum pajak internasional dalam arti sempit adalah kaedah- 
kaedah (norma) hukum perselisihan (kolisi) yang didasarkan pada hukum antar bangsa (hukum internasional). b) Hukum pajak internasional dalam artian luas adalah kaedah-kaedah hukum antarbangsa ini ditambah peraturan nasional yang mempunyai sebagai objeknya hukum perselisihan (kolisi) tentunya yang letaknya dalam bidang perpajakan. (2) Menurut Rossendorff mengartikan hukum pajak internasional sebagai keseluruhan hukum pajak nasional dari semua negara yang ada di dunia. (3) Menurut Van Themaat mendefinisikan hukum pajak internasional sebagai keseluruhan norma-norma, termasuk juga kebiasaan-kebiasaan dan traktat-traktat internasional yang membatasi kedaulatan suatu negara dalam soal pemungutan pajak. (4) Menurut Adriani pengertian hukum pajak internasional merupakan suatu kesatuan hukum yang mengupas suatu persoalan yang diatur dalam undang-undang nasional mengenai: a) Perpajakan terhadap orang-orang luar negeri b) Peraturan-peraturan nasional untuk menghindarkan pajak berganda. c) Traktat-traktat.

\section{Prinsip Pengenaan Pajak}

Setiap negara menerapkan prinsipnya sendiri dalam perundang-undangan yang dijadikan acuan untuk pemungutan pajak. Prinsip tersebut mempengaruhi perlakuan perpajakan terhadap subjek maupun objek pajak luar negeri. Beberapa azas yang dikemukakan oleh Sumitro dalam Surahmat (2000:6), adalah sebagai berikut:

\section{Azas Domisili}

Pengenaan pajak berdasarkan azas domisili berarti bahwa seorang subjek pajak dikenai pajak di negara dimana ia berdomisili. Negara yang menganut pengenaan pajak berdasarkan domisilinya biasanya menganut prinsip world wide income, artinya mereka yang berdomisili di negara tersebut dikenai pajak atas seluruh penghasilan yang bersumber diberbagai negara.

\section{Azas Sumber}

Atas pengenaan berdasarkan sumber adalah pengenaan pajak di negara dimana sumber penghasilan berasal. Penentuan sumber penghasilan tergantung dari dua hal pokok, yaitu jenis penghasilan itu sendiri dan penentuan sumber penghasilan berdasarkan undang-undang pajak dari suatu negara pada umumnya untuk menentukan letak sumber penghasilan, jenis-jenis penghasilan dibagi menjadi dua yaitu: a) Penghasilan dari usaha (active income) b) Penghasilan dari modal (passive income), misalnya dividen, bunga, royalti.

\section{Azas Kewarganegaraan}

Azas kewarganegaraan adalah pengenaan pajak atas dasar status kewarganegaraan wajib pajak. 


\section{Azas Teritorial}

Azas teritorial adalah pengenaan pajak atas penghasilan yang diperoleh dari wilayah suatu negara. Ini berarti bahwa penduduk suatu negara yang menganut azas teritorial hanya akan dikenai pajak atas penghasilan dalam teritorial negara tersebut. Jadi penghasilan yang berasal dari luar negara tersebut tidak akan dikenai pajak di negara ini. Azas ini juga mencakup pengenaan pajak terhadap penduduk luar negeri yang mempunyai atau menguasai harta yang terletak dalam wilayahnya.

\section{Pajak Berganda Internasional}

Menurut Suandi (2008:255) menyatakan bahwa pajak berganda internasional merupakan masalah pokok dalam hukum pajak internasional atau pajak yang dikenakan lebih dari satu kali terhadap objek yang sama oleh lebih dari satu negara, pajak berganda dapat terjadi karena ada lebih dari satu negara yang memungut pajak dan dikenakan pada objek pajak yang sama. Persetujuan penghindaran pajak berganda termasuk salah satu sumber hukum utama perpajakan internasional selain undang-undang perpajakan nasional karena persetujuan ini pada hakikatnya merupakan rekonsiliasi dari dua hukum pajak yang berbeda. Menurut Surahmat (2000:21), terdapat tiga penyebab terjadinya pajak berganda internasional:

\section{Konflik antara Azas Domisili dengan Azas Sumber}

Yang biasanya menjadi penyebab terjadinya pengenaan pajak berganda adalah bertemunya azas domisili dengan azas sumber. Negara domisili mengenakan pajak atas seluruh penghasilan yang diperoleh penduduknya, sedangkan negara sumber mengenakan pajak atas penghasilan yang berasal dari negara tersebut. Dalam hal ini terjadi konflik antara world-wide income principle dan konsep kewenangan atas wilayah.

\section{Konflik karena Perbedaan Definisi Penduduk}

Seorang pribadi atau badan pada saat yang bersamaan dapat dianggap sebagai penduduk dari dua negara. Hal ini dapat terjadi karena definisi penduduk kedua negara tersebut berbeda sehingga pajak yang dikenakan akan menjadi dua kali. Konflik ini akan tampak lebih nyata bila salah satu negara menganut azas kewarganegaraan sebagai kriteria kedua dalam menentukan apakah seseorang merupakan penduduk negara tersebut. Konflik atas penduduk ganda (dual residence) biasanya terjadi atas orang pribadi, tidak halnya dengan badan hukum, karena biasanya pengurus suatu badan hukum berada di negara dimana badan tersebut didirikan. 


\section{Perbedaan Definisi tentang Sumber Penghasilan}

Sebab ini terjadi bila dua negara atau lebih memperlakukan satu jenis penghasilan sebagai penghasilan yang bersumber dari wilayahnya. Hal tersebut menyebabkan penghasilan yang sama dikenai pajak di dua negara.

\section{Kedudukan Perjanjian Penghindaran Pajak Berganda}

Kedududukan hukum P3B dihadapan hukum domestik sangat bervariasi diberbagai negara. Di Indonesia, menurut penjelasan pasal 32A UU PPh yang menegaskan bahwa: Pemerintah berwenang melakukan perjanjian dengan pemerintah negara lain dalam rangka penghindaran pajak berganda dan pencegahan pengelakan pajak dan P3B adalah lex specialis dari UU PPh. Apabila ada konflik antara P3B dengan hukum domestik, maka P3B yang akan berlaku (tax treaty super ceding domestic tax laws).

Menurut Kurniawan dan Muri (2011) dalam Putri (2013:21), P3B tidak memberikan hak pemajakan baru kepada negara yang mengadakan P3B. Pengenaan pajak suatu negara atas suatu jenis penghasilan didasarkan atas ketentuan domestik negara tersebut. Dengan demikian apabila dalam P3B suatu negara diberi hak pemajakan atas suatu penghasilan tertentu akan tetapi negara tersebut berdasarkan hukum domestiknya tidak mengenakan pajak atas penghasilan tertentu tersebut maka negara tersebut tidak dapat mengenakan pajak atas penghasilan tertentu tersebut walaupun P3B memberikan hak pemajakan kepada negara tersebut.

\section{P3B Indonesia-Qatar}

Dari Persetujuan Penghindaran Pajak Berganda (P3B) antara Indonesia-Qatar terdapat pasal-pasal yang mengatur dan berkaitan erat hubungannya dengan perdagangan barang maupun jasa antara kedua belah pihak negara, antara lain: (1) Pasal 1: Orang dan badan yang tercakup dalam persetujuan (Person Covered) (2) Pasal 2: Pajak-pajak yang dicakup dalam persetujuan ini (Tax Covered). (3) Pasal 5: Bentuk Usaha Tetap (Permanent Establishment)

Ayat (2): Istilah "bentuk usaha tetap" terutama meliputi: (a) Suatu tempat kedudukan manajemen (b) Suatu cabang (c) Suatu kantor (d) Suatu pabrik (e) Suatu bengkel (f) Suatu gudang atau tempat penyimpanan barang sebagai tempat penjualan. (g) Suatu pertanian atau perkebunan (h) Suatu tambang, suatu sumur atau gas, suatu penggalian atau tempat eksplorasi atau eksploitasi sumber daya alam, rig untuk pengeboran atau kapal yang digunakan untuk eksplorasi atau eksploitasi sumber daya alam.

Ayat (3): Istilah "bentuk usaha tetap" juga meliputi: suatu bangunan, suatu konstruksi, proyek atau perakitan atau proyek instalasi atau kegiatan pengawasan yang ada hubungan dengan proyek tersebut, tetapi hanya apabila bangunan, proyek atau kegiatan tersebut berlangsung untuk masa lebih dari 6 (enam) bulan pemberian 
jasa termasuk jasa konsultan yang dilakukan oleh suatu perusahaan melalui karyawannya atau orang lain yang dipekerjakan oleh perusahaan itu untuk tujuan tersebut, tetapi hanya apabila kegiatan-kegiatan tersebut berlangsung (untuk proyek yang sama atau ada kaitannya) di suatu negara dalam masa atau masa-masa yang berjumlah lebih dari enam bulan dalam jangka waktu dua belas bulan.

\section{Pasal 7: Laba Usaha (Busines Profit)}

Ayat (1) Laba perusahaan dari Negara pihak pada persetujuan hanya akan dikenakan pajak di Negara itu kecuali jika perusahaan itu menjalankan usaha di Negara pihak lainnya pada persetujuan melalui suatu bentuk usaha tetap. Apabila perusahaan tersebut menjalankan usahanya sebagaimana dimaksud di atas, laba perusahaan itu dapat dikenakan pajak di Negara lainnya tetapi hanya atas bagian laba yang berasal dari: a) Bentuk Usaha Tetap tersebut, dan b) Penjualan yang dilakukan di Negara lainnya atas barang-barang atau barang dagangan yang sama atau serupa jenisnya dengan yang dijual melalui bentuk usaha tetap itu atau kegiatankegiatan usaha lainnya yang dijalankan di Negara lain itu yang sama atau serupa jenisnya dengan yang dilakukan melalui bentuk usaha tetap itu.

Menurut Kurniawan dan Muri (2011) dalam Putri (2013:22-23) pasal-pasal Tax Treaty di atas mengemukakan tentang: Pasal 1 mengenai subjek yang dicakup dalam P3B, yaitu subjek pajak yang menjadi penduduk salah satu atau kedua Negara yang terikat persetujuan. P3B menggunakan istilah "persons" yang mengandung arti orang pribadi (individual), badan (company) dan kumpulan orang pribadi atau badan yang merupakan satu kesatuan. Sedangkan Pasal 2 mengenai pajak yang lazim dicakup dalam P3B adalah pajak yang dapat menimbulkan masalah pengenaan pajak berganda internasional yaitu pajak penghasilan yang dihasilkan atas transaksitransaksi perdagangan, penyertaan modal maupun investasi. Dalam Pasal 5 ayat (2),(3) menjelaskan kegiatan usaha seperti apa yang dapat dikategorikan sebagai BUT dan kegiatan seperti apa yang tidak dapat dikategorikan sebagai BUT. Dan pasal 7 ayat (1) model P3B Indonesia, jika perusahaan yang merupakan mitra P3B menjalankan usahanya dinegara lainnya melalui BUT yang ada di Negara lainnya tersebut, maka laba usaha dapat dikenakan pajak di Negara lainnya yang dimaksudkan di atas.

Jadi P3B berlaku bagi orang pribadi atau badan yang menjadi salah satu atau kedua Negara yang terikat persetujuan. Dengan demikian penduduk Negara di luar kedua Negara yang terikat persetujuan tersebut tidak berhak menikmati perlindungan $\mathrm{P} 3 \mathrm{~B}$.

Keberadaan tax treaty membuat ketentuan perpajakan domestik kedua negara tidak berlaku. Sebagaimana dijelaskan di atas, dapat dilihat bahwa tarif Pajak Penghasilan turun dari 20\% menjadi 10\%. Penurunan ini terjadi ketika tarif kesepakatan P3B Indonesia-Qatar disepakati seperti tabel berikut ini: 
Tabel 1. Tarif Pemajakan Sebelum dan Sesudah Disepakatinya P3B Indonesia-Qatar

\begin{tabular}{lll}
\hline Jenis Pemajakan & Ta rif Sebelum P3B & Tarif Sesudah P3B \\
\hline Dividen Portofolio & $20 \%$ & $10 \%$ \\
Dividen Penyertaan Langsung & $20 \%$ & $10 \%$ \\
Bunga & $20 \%$ & $10 \%$ \\
Royalti & $20 \%$ & $5 \%$ \\
PPh Ps. 26 ayat 4 (Branch Profit Tax) & $20 \%$ & $5 \%$ \\
\hline
\end{tabular}

Dengan turunnya tarif perpajakan yang menjadi kesepakatan pada sektor perdagangan tentunya akan sangat menguntungkan bagi kedua Negara persetujuan penghindaran pajak berganda disektor perdagangan khususnya, tetapi persetujuan tidaklah selamanya menguntungkan pasti ada sisi negatif dimana jika Negara persetujuan sudah bergantung atas Negara lainnya sehingga ada sisi ketidakmandirian sebuah Negara dalam urusan keperluan di dalam negeri. Di sisi positif tentunya sebuah Negara menjalin kerjasama dibidang-bidang yang menjadi persetujuan sehingga tercapainya sebuah mufakat untuk kepentingan kedua Negara dalam urusan perpajakan.

\section{METODOLOGI PENELITIAN}

\section{Jenis Penelitian}

Penelitian ini merupakan penelitian kuantitatif, dimana penelitian ini memperoleh data dalam bentuk angka atau data kualitatif yang diangkakan. Menurut Sugiono (2014:35) menyatakan, data penelitian yang digunakan adalah data sekunder yang didapatkan dari Kementrian Perdagangan Republik Indonesia. P3B Indonesia-Qatar disepakati pada tanggal 1 Januari 2008 sehingga sampel pada penelitian ini menggunakan data realisasi ekspor-impor tahun 2004 sampai 2011 di mana pada penelitian ini akan dibanding empat tahun sebelum disepakatinya P3B (data realisasi eksporimpor tahun 2004-2007) dan 4 tahun sesudah disepakatinya P3B (data realisasi ekspor-impor tahun 2008-2011), di mana dalam tiap tahunnya terdapat 12 bulan.

\section{Uji Normalitas}

Uji normalitas ini bertujuan untuk menguji apakah dalam model regresi, variabel pengganggu atau residual memiliki distribusi normal (Ghozali, 2011). Cara untuk mendeteksi apakah residual berdistribusi normal atau tidak, yaitu dengan uji statistik (uji Kolmogorof Smirnov). Dari hasil pengujian didapatkan nilai kolmogorof smirnov untuk nilai ekspor sebelum P3B sebesar 0,226 sedangkan setelah P3B 0,504, maka dapat disimpulkan bahwa untuk nilai perdagangan ekspor data terdistribusi dengan normal.

Untuk nilai perdagangan impor, dari hasil pengujian menunjukkan nilai kolmogorov smirnov untuk periode sebelum P3B memiliki nilai 0.571, sedangkan periode 
setelah P3B sebesar 0.245, maka dapat disimpulkan bahwa data nilai perdagangan impor terdistribusi normal.

\section{HASIL PENELITIAN DAN PEMBAHASAN}

\section{Temuan Penelitian}

Qatar merupakan sebuah Negara yang terletak disebuah semenanjung kecil di Jazirah Arab. Awalnya ekonomi Qatar difokuskan pada perikanan dan mutiara yang dibudidayakan, tetapi transformasi perekonomian pun terjadi pada tahun 1940 saat temuan minyak bumi di Negara tersebut. Dengan kekayaan minyak bumi dan gas alamnya terbesar ketiga di dunia membuat Negara ini berinvestasi besar-besaran diinfrastruktur untuk melancarkan dan mengekspor komoditas tersebut. Qatar juga mengembangkan usaha disektor perbankan dengan mendirikan sebuah bank syariah di Indonesia. Sementara itu Indonesia sendiri mengekspor barang dan jasa berupa tenaga-tenaga ahli konstruksi, furniture, pelumas mesin, kayu, kertas, plastik, tekstil, pakaian jadi, serta alat-alat listrik dan makanan segar.

Pada tahun 2004 sampai dengan 2007, yaitu saat sebelum disepakatinya P3B, perdagangan Indonesia dan Qatar antara ekspor dan impor kedua Negara itu terlihat dari neraca perdagangan Indonesia-Qatar dengan nilai ekspor sebesar U\$D 345.290.989 sedangkan impornya sebesar U\$D 331.235.543. Sedangkan pada tahun setelah disepakatinya P3B antara tahun 2008 sampai 2011 perdagangan Indonesia dan Qatar antara ekspor dan impor sudah menunjukkan kenaikan drastis atas nilai impor, komoditas yang diimpor dari Qatar yang sangat signifikan meningkat yaitu berupa impor minyak bumi dan gas alam dengan nilai impor sebesar U\$D 1.686.796.889 berbanding terbalik dengan nilai ekspor yang hanya sebesar U\$D 307.379.579.

Atas P3B yang disepakati oleh kedua negara dapat terlihat tingkat signifikan impor Indonesia yang begitu naik drastis, hal tersebut juga akibat faktor terjadinya kebutuhan akan minyak bumi dan gas alam di Indonesia, maka sebagai partner yang berlatarbelakang sebagai Negara terbesar ketiga akan kekayaan minyak dan gas alamnya, sudah tentu Indonesia mengimpor komoditas yang menjadi kebutuhan Negara dengan Negara partner P3B yaitu Qatar. Indonesia juga memperoleh keuntungan tentunya atas disepakatinya P3B tersebut berupa kesepakatan-kesepakatan kerjasama yang banyak menggunakan jasa-jasa perdagangan dari Indonesia berupa kenaikan dibidang perdagangan non migas

\section{Statistik Deskriptif}

\section{Perdagangan Ekspor}

Di dalam sektor ekspor, data memungkinkan untuk mengkhususkan menjadi 2 kategori yaitu ekspor migas dan non migas, data sampel ekspor migas sebelum 
P3B berjumlah 48 dengan terjadi transaksi 43 bulan dan 0 transaksi sebanyak 5 bulan sedangkan data ekspor migas sesudah P3B sebanyak 48 dengan terjadi transaksi 34 bulan dan 0 transaksi sebanyak 12 bulan. Sedangkan data untuk ekspor nonmigas berjumlah 48 bulan transaksi untuk sesudah dan sebelum P3B disepakati. Berikut hasil temuan ekspor:

Tabel 2. Descriptive Statistics Ekspor

\begin{tabular}{lccccc}
\hline & N & Mean & $\begin{array}{c}\text { Std. } \\
\text { Deviation }\end{array}$ & Minimum & Maximum \\
\hline Ekspor Sebelum P3B & 48 & 7193562.271 & $4.7225 \mathrm{E} 6$ & 1219034.0 & 19703926.0 \\
Ekspor Sesudah P3B & 48 & 6403741.229 & $2.0944 \mathrm{E} 6$ & 3205247.0 & 13982654.0 \\
\hline
\end{tabular}

Tabel di atas menunjukkan bahwa nilai rata-rata ekspor sesudah P3B menurun dibandingkan dengan periode sebelum P3B. Suatu kondisi perdagangan yang kurang menguntungkan bagi pihak negara Indonesia jika dilihat dari keseluruhan umum tentunya, ini dikarenakan perubahan tarif perpajakan setelah P3B hanya menyepakati dan menitikberatkan pada penghasilan sektor non migas secara khusus yang tertuang pada draft P3B Indonesia-Qatar, sehingga ekspor Indonesia tidak meningkat jika dilihat secara keseluruhan. Ini membuat terjadinya kenaikan tarif pajak atas pengenaan pajak barang maupun jasa yang diekspor dari Indonesia terhadap Qatar.

\section{Perdagangan Ekspor Migas}

Tabel 3. Descriptive Statistics Ekspor Migas Descriptive Statistics Ekspor Migas

\begin{tabular}{llllll}
\hline \multicolumn{1}{c}{$\mathbf{N}$} & \multicolumn{1}{c}{ Mean } & \multicolumn{1}{c}{$\begin{array}{c}\text { Std. } \\
\text { Deviation }\end{array}$} & \multicolumn{1}{c}{ Minimum } & \multicolumn{1}{c}{ Maximum } \\
\hline Ekspor Migas Sebelum P3B & 48 & 2507853.646 & $2.3890 \mathrm{E} 6$ & .0 & 10199100.0 \\
Ekspor Migas Sesudah P3B & 48 & 526100.063 & 566664.3359 & .0 & 2522500.0 \\
\hline
\end{tabular}

Dari tabel 3 diketahui bahwa nilai perdagangan ekspor migas antara IndonesiaQatar periode tahun 2004 sampai dengan 2011 memiliki nilai minimum periode sebelum P3B sebesar 0,00 dan nilai minimum periode sesudah P3B sebesar 0,00 sedangkan nilai maksimum periode sebelum P3B sebesar 10199100,0 dan nilai maksimum periode sesudah P3B sebesar 2522500,0. Nilai rata-rata periode sebelum P3B sebesar 2597853,646 dan nilai rata-rata periode sesudah P3B sebesar 526100,063. Standar deviasi pada periode sebelum P3B sebesar 2,38906E dan standar deviasi periode sesudah P3B sebesar 566664,3359. Ini menunjukkan bahwa nilai rata-rata ekspor migas sesudah $\mathrm{P} 3 \mathrm{~B}$ menurun dibandingkan dengan periode sebelum P3B. Kondisi perdagangan seperti ini dikarenakan Indonesia hanya mengekspor barang-barang migas yang berupa migas olahan, bukanlah sebagai pengekspor migas alam sebagaimana komoditas Negara-negara Timur-Tengah yang 
berlatar belakang Negara penghasil minyak bumi. Perubahan tarif pajak atas draft P3B hanya menitikberatkan atas penurunan tarif pajak penghasilan dikedua Negara.

\section{Perdagangan Ekspor Non Migas}

Tabel 4. Descriptive Statistics Ekspor Non Migas

\begin{tabular}{lcclcc}
\hline \multicolumn{1}{c}{$\mathbf{N}$} & \multicolumn{1}{c}{ Mean } & Std. Deviation & \multicolumn{1}{c}{ Minimum } & Maximum \\
\hline $\begin{array}{l}\text { Ekspor Ekspor Non Migas } \\
\text { Sebelum P3B }\end{array}$ & 48 & 4685708.625 & $2.9058 \mathrm{E} 6$ & 808973.0 & 13188886.0 \\
$\begin{array}{l}\text { Ekspor Non Migas Sesudah } \\
\text { P3B }\end{array}$ & 48 & 5877641.167 & $1.7443 \mathrm{E} 6$ & 3205247.0 & 12068574.0 \\
& & & & & \\
\hline
\end{tabular}

Dari tabel 4 diketahui bahwa nilai perdagangan ekspor non migas antara Indonesia-Qatar periode tahun 2004 sampai dengan 2011 memiliki nilai minimum periode sebelum P3B sebesar 808973,0 dan nilai minimum periode sesudah P3B sebesar 3205247.0 sedangkan nilai maksimum periode sebelumP3B sebesar 13188886.0 dan nilai maksimum periode sesudah P3B sebesar 12068574,0. Nilai rata-rata periode sebelum P3B sebesar 4685708,625 dan nilai rata-rata periode sesudah P3B sebesar 5877641,167. Standar deviasi pada periode sebelum P3B sebesar 2,9058E6 dan standar deviasi periode sesudah P3B sebesar 1,7443E6. Ini menunjukkan bahwa nilai rata-rata ekspor nonmigas sesudah $\mathrm{P} 3 \mathrm{~B}$ naik dibandingkan dengan periode sebelum P3B. Kondisi perdagangan seperti ini dikarenakan terjadinya perubahan tarif pajak yang cukup menguntungkan disektor nonmigas yang meliputi ekspor barang maupun jasa.

\section{Perdagangan Impor}

Pada perdagangan impor data tidak memungkinkan dikhususkan menjadi 2 seperti data yang terlihat pada tabel 4 di atas, sehingga pengujian impor hanya dilakukan pengujian umum untuk semua impor yang terjadi antara Indonesia-Qatar, berikut temuan penelitian atas impor:

Tabel 5. Descriptive Statistics Impor

\begin{tabular}{lcllll}
\hline & N & Mean & Std. Deviation & Minimum & Maximum \\
\hline Impor Sebelum P3B & 48 & 6900740.479 & $4.1728 \mathrm{E} 6$ & 1087999.0 & 22217688.0 \\
Impor Sesudah P3B & 48 & $3.514 \mathrm{E7}$ & $3.0491 \mathrm{E} 7$ & 116548.0 & 170410797.0 \\
\hline
\end{tabular}

Dari tabel 5, diketahui bahwa nilai perdagangan impor antara Indonesia-Qatar periode tahun 2004 sampai dengan 2011 memiliki nilai minimum periode sebelum P3B sebesar 1087999,0 dan nilai minimum periode sesudah P3B sebesar 116548,0 sedangkan nilai maksimum periode sebelum P3B sebesar 22217688,0 dan nilai maksimum periode sesudah P3B sebesar 170410797,0. Nilai rata-rata periode sebelum P3B sebesar 6900740,479 dan nilai rata-rata periode sesudah P3B sebesar 
3514E7. Standar deviasi pada periode sebelum P3B sebesar 4,1728E6 dan standar deviasi periode sesudah P3B sebesar 3,0491E7. Ini menunjukkan bahwa nilai ratarata impor sesudah P3B naik dibandingkan dengan periode sebelum P3B. Kondisi ini dikarenakan turunnya tarif pemajakan atas transaksi perdagangan tersebut.

Suatu kondisi perdagangan yang sangat menguntungkan bagi pihak Negara Qatar, ini dikarenakan turunnya tarif pemajakan di Indonesia atas barang maupun jasa dari Negara Qatar yang menjadi objek pajak. Dan terlihat sangat signifikan perubahannya, di mana kembali lagi pada tarif pemajakan di Indonesia yang notabenenya merupakan Negara pajak atas dasar Undang-Undang Pajak Penghasilan Nomor 36 Tahun 2008 yang menyatakan bahwa penghasilan yang dibayarkan kepada pihak luar negeri terutang pajak penghasilan dengan tarif 20\%. Sedangkan pada perubahan tarif P3B yang tertera pada draft Tax Treaty Indonesia-Qatar pemajakan atas dividen $10 \%$, bunga $10 \%$, royalti $5 \%$ dan branch profit tax sebesar 5\%. Ini membuat terjadinya penurunan tarif pajak atas pemajakan barang maupun jasa yang diimpor oleh Indonesia terhadap Qatar.

\section{Perbandingan Nilai Ekspor Sebelum dan Setelah Kesepakatan P3B}

Uji Paired Sample T-Test atau uji beda rata-rata dua sampel berpasangan ini dimaksudkan untuk menguji ada tidaknya perbedaan Mean untuk dua sampel yang saling berhubungan (dependent).

Tabel 6. Analisis Perbedaan Nilai Perdagangan Ekspor Sebelum dan Sesudah P3B

\begin{tabular}{|c|c|c|c|c|c|c|c|c|}
\hline & \multirow{3}{*}{ Mean } & \multicolumn{4}{|c|}{ Paired Differences } & \multirow{3}{*}{$\mathbf{t}$} & \multirow{3}{*}{ df } & \multirow{3}{*}{$\begin{array}{c}\text { Sig. } \\
\text { (2-tailed) }\end{array}$} \\
\hline & & \multirow{2}{*}{$\begin{array}{c}\text { Std. } \\
\text { Dev iation }\end{array}$} & \multirow{2}{*}{$\begin{array}{l}\text { Std. Error } \\
\text { Mean }\end{array}$} & \multicolumn{2}{|c|}{$\begin{array}{l}\text { 95\% Confidence Interval } \\
\text { of the Difference }\end{array}$} & & & \\
\hline & & & & Lower & Upper & & & \\
\hline $\begin{array}{l}\text { Eks_Sebel } \\
\text { um_P3B - } \\
\text { Eks_Sesud } \\
\text { ah_P3B }\end{array}$ & 789821.0417 & $5.1122 \mathrm{E} 6$ & 737888.5268 & -694619.2023 & $2.2743 \mathrm{E} 6$ & 1.070 & 47 & .290 \\
\hline
\end{tabular}

Pada tabel 6, menunjukkan bahwa probabilitas Sig. (2 tailed) sebesar 0,290 ini berarti bahwa nilai ekspor sebelum dan sesudah P3B secara umum tidak memiliki nilai perbedaan secara nyata, karena nilai probabilitas Sig.(2 tailed) sebesar 0,290 $>0,05$ pada taraf kepercayaan 95\%. Maka dapat ditarik kesimpulan H1 ditolak yaitu tidak adanya perbedaan yang nyata secara signifikan nilai perdagangan ekspor secara umum antara sebelum dan sesudah disepakatinya persetujuan penghindaran pajak berganda antara Indonesia-Qatar sehingga yang terjadi bagi para eksportireksportir Indonesia tidak cukup signifikan pada sektor migas, terlihat pada tarif pemajakan di Qatar yang notabenenya adalah Negara havent tax country hanya memungut tarif pemajakan atas barang maupun jasa impor di Negara Qatar hanya 5\% saja, sedangkan pada perubahan tarif P3B yang tertera pada draft Tax Treaty Indonesia-Qatar pemajakan atas dividen $10 \%$, bunga $10 \%$, royalti $5 \%$ dan branch 
profit tax sebesar 5\%. Ini membuat terjadinya penurunan tarif pajak dari sektor pemajakan atas penghasilan atas barang dan jasa sedangkan untuk barang-barang tambang khususnya migas olahan yang di ekspor dari Indonesia mengalami pemajakan yang tetap yaitu $5 \%$ untuk bea masuk. Tentu saja dalam kondisi ini pemerintah Negara Indonesia tidak memperoleh keuntungan atas penetapan pemajakan yang statis untuk beberapa barang yang diekspor. Sedangkan keuntungan bagi eksportireksportir dari Indonesia berupa penurunan pemajakan dari sektor pemajakan penghasilan serta memperoleh keuntungan tidak terjadinya penarikan pajak berganda dan bisa dikredit pajakkan atas pajak yang dikenakan di luar negeri sebut Qatar.

\section{Perbandingan Nilai Ekspor Migas}

Tabel 7. Analisis Perbedaan Nilai Perdagangan Ekspor Migas Sebelum dan Sesudah P3B

\begin{tabular}{|c|c|c|c|c|c|c|c|c|}
\hline & \multirow{3}{*}{ Mean } & \multicolumn{4}{|c|}{ Paired Differences } & \multirow{3}{*}{$\mathbf{t}$} & \multirow{3}{*}{ df } & \multirow{3}{*}{$\begin{array}{l}\text { Sig. (2- } \\
\text { tailed) }\end{array}$} \\
\hline & & $\begin{array}{c}\text { Std. } \\
\text { Deviation }\end{array}$ & $\begin{array}{l}\text { Std. Error } \\
\text { Mean }\end{array}$ & \multicolumn{2}{|c|}{$\begin{array}{l}95 \% \text { Confidence } \\
\text { Interval of the } \\
\text { Difference }\end{array}$} & & & \\
\hline & & & & Lower & Upper & & & \\
\hline $\begin{array}{l}\text { Eks_Sebel } \\
\text { um_P3B - } \\
\text { Eks_Sesu } \\
\text { dah_P3B }\end{array}$ & $1.9818 \mathrm{E} 6$ & $2.518 \mathrm{E} 6$ & 363617.0146 & $1.2503 \mathrm{E} 6$ & $2.7133 \mathrm{E} 6$ & 5.450 & 47 & .000 \\
\hline
\end{tabular}

Pada tabel 7 menunjukkan bahwa probabilitas Sig. (2 tailed) sebesar 0,000 ini berarti bahwa nilai ekspor sebelum dan sesudah P3B memiliki nilai perbedaan secara nyata, karena nilai probabilitas Sig. (2 tailed) sebesar 0,000 $<0,05$ pada taraf kepercayaan 95\%. Maka dapat ditarik kesimpulan $\mathrm{H} 1 \mathrm{a}$ diterima yaitu adanya perbedaan yang nyata secara signifikan nilai perdagangan ekspor migas antara sebelum dan sesudah disepakatinya persetujuan penghindaran pajak berganda antara Indonesia-Qatar. Kondisi perdagangan seperti ini dikarenakan Indonesia hanya mengekspor barang-barang migas yang berupa migas olahan, bukanlah sebagai pengekspor migas alam sebagaimana komoditas negara-negara timur-tengah yang berlatar belakang Negara penghasil minyak bumi. Ekspor migas kurang berkaitan erat atas penurunan tarif pajak penghasilan P3B yang berlaku sehingga atas ekspor migas tersebut tarif yang berlaku tetap 5\% sebesar ketetapan bea masuk di Negara Qatar dan keuntungan bagi eksportir-eksportir dari Indonesia memperoleh keuntungan tidak terjadinya penarikan pajak berganda dan bisa dikredit pajakkan atas pajak yang dikenakan di luar negeri sebut Qatar. 


\section{Perbandingan Nilai Ekspor Nonmigas}

Tabel 8. Analisis Perbedaan Nilai Perdagangan Ekspor Non Migas Sebelum dan Sesudah P3B

\begin{tabular}{|c|c|c|c|c|c|c|c|c|}
\hline & \multirow{3}{*}{ Mean } & \multicolumn{4}{|c|}{ Paired Differences } & \multirow{3}{*}{$\mathbf{t}$} & \multirow{3}{*}{ df } & \multirow{3}{*}{$\begin{array}{l}\text { Sig. (2- } \\
\text { tailed) }\end{array}$} \\
\hline & & \multirow{2}{*}{$\begin{array}{c}\text { Std. } \\
\text { Deviation }\end{array}$} & \multirow{2}{*}{$\begin{array}{l}\text { Std. Error } \\
\text { Mean }\end{array}$} & \multicolumn{2}{|c|}{$\begin{array}{c}\text { 95\% Confidence Interval } \\
\text { of the Difference }\end{array}$} & & & \\
\hline & & & & Lower & Upper & & & \\
\hline $\begin{array}{l}\text { Eks_Sebelu } \\
\text { m_P3B - }\end{array}$ & $-1.191 \mathrm{E} 6$ & 3.2036E6 & 462396.0198 & $-2.1222 \mathrm{E} 6$ & -261711.7353 & -2.578 & 47 & .013 \\
\hline $\begin{array}{l}\text { Eks_Sesuda } \\
\text { h_P3B }\end{array}$ & & & & & & & & \\
\hline
\end{tabular}

Pada tabel 8, menunjukkan bahwa probabilitas Sig. (2 tailed) sebesar 0,013 ini berarti bahwa nilai ekspor non migas sebelum dan sesudah P3B memiliki nilai perbedaan secara nyata, karena nilai probabilitas Sig. (2 tailed) sebesar 0,013< 0,05 pada taraf kepercayaan 95\%. Maka dapat ditarik kesimpulan H1b diterima yaitu adanya perbedaan yang nyata secara signifikan nilai perdagangan ekspor nonmigas antara sebelum dan sesudah disepakatinya persetujuan penghindaran pajak berganda antara Indonesia-Qatar. Kondisi perdagangan seperti ini dikarenakan terjadinya perubahan tarif pajak yang cukup menguntungkan disektor nonmigas yang meliputi ekspor barang maupun jasa. Berikut penurunan tarif pemajakan sebelum dan sesudah P3B Indonesia-Qatar:

Penurunan perubahan tarif pemajakan yang terjadi bagi para eksportir-eksportir Indonesia cukup signifikan perubahannya, terlihat pada tarif pemajakan Qatar yang notabennya adalah Negara havent tax country hanya memungut tarif pemajakan atas barang maupun jasa impor di Negara Qatar hanya 5\% saja, sehingga untuk pemajakan didasarkan atas asas domisili (resident jurisdiction) yang mana Indonesia sebagai Negara domisili dan pemajakan berdasarkan tarif Undang-Undang Pajak Penghasilan Nomor 36 Tahun 2008 yang menyatakan bahwa penghasilan yang dibayarkan kepada pihak luar negeri terutang pajak penghasilan dengan tarif $20 \%$ . Sedangkan yang berlaku perubahan tarif P3B yang tertera pada draft Tax Treaty Indonesia-Qatar pemajakan atas dividen $10 \%$, bunga $10 \%$, royalti $5 \%$ dan branch profit tax sebesar 5\%. Ini membuat terjadinya penurunan tarif pajak atas pemajakan barang maupun jasa yang diekspor dari Indonesia terhadap Qatar yang berkewajiban membayar pajak atas dasar asas domisili. 


\section{Perbandingan Nilai Impor}

Tabel 9. Analisis Perbedaan Nilai Perdagangan Ekspor Impor Sebelum dan Sesudah P3B

\begin{tabular}{|c|c|c|c|c|c|c|c|c|}
\hline & \multirow{3}{*}{ Mean } & \multicolumn{4}{|c|}{ Pa ired Differences } & \multirow{3}{*}{$\mathbf{T}$} & \multirow{3}{*}{ df } & \multirow{3}{*}{$\begin{array}{l}\text { Sig. (2- } \\
\text { tailed) }\end{array}$} \\
\hline & & $\begin{array}{c}\text { Std. } \\
\text { Deviation }\end{array}$ & $\begin{array}{c}\text { Std. Error } \\
\text { Mean }\end{array}$ & \multicolumn{2}{|c|}{$\begin{array}{l}95 \% \text { Confidence } \\
\text { Interval of the } \\
\text { Difference }\end{array}$} & & & \\
\hline & & & & Lower & Upper & & & \\
\hline $\begin{array}{l}\text { Eks_Sebelu } \\
\text { m_P3B - } \\
\text { Eks_Sesuda } \\
\text { h_P3B }\end{array}$ & $-2.824 \mathrm{E} 7$ & $3.1814 \mathrm{E} 7$ & $4.5920 \mathrm{E} 6$ & 3.7479E7 & $-1.9003 \mathrm{E} 7$ & $\begin{array}{l}- \\
6.150\end{array}$ & 47 & .000 \\
\hline
\end{tabular}

Pada tabel 9 menunjukkan bahwa probabilitas Sig. (2 tailed) sebesar 0,000 ini berarti bahwa nilai impor sebelum dan sesudah P3B memiliki nilai perbedaan secara nyata, karena nilai probabilitas Sig. (2 tailed) sebesar 0,000 $<0,05$ pada taraf kepercayaan $95 \%$. Maka dapat ditarik kesimpulan $\mathrm{H} 2$ diterima yaitu adanya perbedaan yang nyata nilai perdagangan impor antara sebelum dan sesudah disepakatinya persetujuan penghindaran pajak berganda antara Indonesia-Qatar. Hal ini dikarenakan turunnya tarif pemajakan di Indonesia atas perdagangan impor di Indonesia. Dan terlihat sangat signifikan perubahannya, di mana kembali lagi pada tarif pemajakan di Indonesia yang notabenenya merupakan Negara pajak atas dasar UndangUndang Pajak Penghasilan Nomor 36 Tahun 2008 yang menyatakan bahwa penghasilan yang dibayarkan kepada pihak luar negeri terutang pajak penghasilan dengan tarif $20 \%$. Sedangkan pada perubahan tarif P3B yang tertera pada draft Tax Treaty Indonesia-Qatar pemajakan atas dividen 10\%, bunga 10\%, royalti 5\% dan branch profit tax sebesar 5\%. Ini membuat terjadinya penurunan tarif pajak atas pemajakan barang maupun jasa yang diimpor oleh Indonesia terhadap Qatar. Tentu saja dalam kondisi ini para eksportir Qatar lah yang memperoleh keuntungan atas penurunan tarif atas pajak barang atau jasa yang diimpor ke Indonesia. Sedangkan keuntungan bagi pemerintah yaitu memperoleh pendapatan pajak yang lebih besar jika imporimpor barang dan jasa terhadap Indonesia meningkat tajam, disisi lain pemerintah Indonesia juga dirugikan karena atas impor yang besar atas Qatar maka akan mengurangi devisa Negara sebagai alat pembayaran.

\section{SIMPULAN}

Dari hasil penelitian dan pembahasan yang dilakukan dapat ditarik kesimpulan bahwa analisis perdagangan ekspor setelah disepakatinya P3B antara IndonesiaQatar dapat dilihat dari segi ekspor secara umum dan ekspor secara khusus yaitu: Pertama, Ekspor dari segi umum atas disepakatinya P3B antara Indonesia-Qatar terlihat tidak menampakkan perbedaan yang nyata secara signifikan dikarenakan P3B yang disepakati hanya menitikberatkan pada pemajakan yang bersifat pajak penghasilan, di mana pajak-pajak atas penghasilan lebih mendekati ekspor-ekspor 
nonmigas daripada ekspor migas antara kedua Negara perjanjian. Kedua, Ekspor migas mengalami penurunan nilai perdagangan dengan mean ekspor migas sebelum P3B sebesar 2507853,646 menjadi 526100,063 setelah P3B dengan sig. (2 tailed) sebesar $0,000<0,05$ hal ini berarti tidak ada perbedaan perdagangan di sektor migas sebelum dan sesudah disepakatinya P3B antara Indonesia-Qatar. Sedangkan pada ekspor non migas terdapat perbedaan yang siginifikan dapat dilihat dari kenaikan nilai perdagangan dengan mean ekspor nonmigas sebelum P3B sebesar 4685708,625 menjadi 5877641,147 setelah P3B dan sig. (2 tailed) sebesar 0,013 < 0,05. Hal demikian terjadi karena $\mathrm{P} 3 \mathrm{~B}$ yang disepakati lebih menitikberatkan pada pemajakan atas pajak penghasilan, sehingga ekspor-ekspor atas nonmigas mengalami trend kenaikan.

Analisis perdagangan impor atas disepakatinya persetujuan penghindaran pajak berganda antara Indonesia-Qatar terlihat menampakkan perbedaan yang nyata secara signifikan dibuktikan oleh hasil pengujian statistik dengan sig.(2tailed) sebesar $0,000<0,05$ pada taraf kepercayaan $95 \%$ sehingga hipotesis diterima dengan adanya perbedaan perdagangan disektor impor.

Berdasarkan hasil penelitian yang dilakukan persetujuan penghindaran pajak berganda dapat menjadi sebuah peluang menjalin hubungan perdagangan yang lebih baik untuk kedua Negara perjanjian, akan tetapi jika pihak Negara Indonesia tidak memanfaatkan persetujuan ini justru akan menjadi kerugian karena banyaknya produk-produk barang maupun jasa asing yang masuk. Untuk pengembangan penelitian dimasa akan datang diharapkan lebih mengembangkan sampel area penelitian sehingga dapat diketahui dampak dari P3B terhadap Negara-negara dibelahan dunia lainnya.

\section{DAFTAR PUSTAKA}

Ghozali, I. 2011. Aplikasi Analisis Multivariate Dengan Program IBM SPSS 19. Semarang: Badan Penerbit Universitas Diponegoro.

KBRI. 2012. KBRI Doha Meningkatkan Totalitas Diplomasi RI-Qatar. http://www. tabloiddiplomasi.org/previous-isuue/170-april-2012/1394-kbri-doha-meningkatkantotalitas-diplomasi-ri-qatar-.html diunduh pada 25 Nopember 2014.

Kementerian Keuangan Republik Indonesia. 2012. Tax Treaty dan Pengaruhnya Terhadap Arus Investasi antara Indonesia dengan Negara-negara Mitra. http://www.kemenkeu. go.id/kajian.pkrb_taxtreaty diunduh pada 23 Januari 2015.

Pranata. 2012. Ini Dia 8 Negara Bebas Pajak Penghasilan. http://www.finance.detik.com/ $\mathrm{read} / 2012 / 07 / 16 / 085125 / 1965942 / 4 / 8 /$ ini-dia-8-negara-bebas-pajak-penghasilan diunduh pada 25 Nopember 2014.

Priyatno, D. 2010. Paham Analisa Statistik Data dengan SPSS. Yogyakarta: MediaKom.

Putri, R.D. 2013. Analisis Persetujuan Penghindaran Pajak Berganda IndonesiaHongkong. Jakarta: Fakultas Ekonomi Universitas Indonesia. 
Republik Indonesia. Peraturan Direktur Jendral Pajak Nomor PER-61/PJ/2009/, tanggal 5 November 2009, tentang Tata Cara Penerapan Persetujuan Penghindaran Pajak Berganda.

Republik Indonesia. Peraturan Direktur Jendral Pajak Nomor PER-48/PJ/2010, Tanggal 3 November 2010, tentang Tata Cara Pelaksanaan Prosedur Persetujuan Bersama ( $\mathrm{Mu}$ tual Agreement Procedure) Berdasarkan Persetujuan Penghindaran Pajak Berganda.

Republik Indonesia. Undang- Undang Nomor 36 Tahun 2008, tanggal 23 September 2008 tentang Pajak Penghasilan.

Republik Indonesia. Undang-Undang Republik Indonesia Nomor 10 Tahun 1995 tentang Kepabeanan.

Republik Indonesia. Undang-Undang Republik Indonesia Nomor 42 Tahun 2009 Tentang Perubahan Ketiga Atas Undang-Undang Nomor 8 Tahun 1983 Tentang Pajak Pertambahan Nilai Barang dan Jasa dan Pajak Penjualan Atas Barang Mewah.

Suandi, E. 2008. Hukum Pajak. Jakarta: Salemba Empat.

Sugiyono. 2014. Metodologi Penelitian Manajemen. Bandung: Alfabeta.

Surahmat, R. 2000. Persetujuan Penghindaran Pajak Berganda Sebuah Pengantar. Jakarta: Gramedia Pustaka Utama.

Yuniati, Rini. 2011. Faktor-Faktor Perekonomian Indonesia di Era Globalisasi terhadap Perdagangan Internasional. Bandung: Fakultas Ekonomi Universitas Pendidikan Indonesia. 